\title{
Toward an urgent yet deliberate conservation strategy: sustaining social- ecological systems in rangelands of the Northern Great Plains, Montana
}

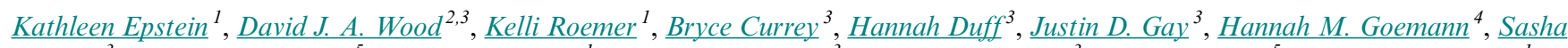

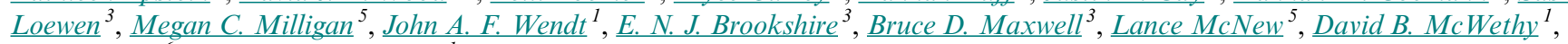 \\ Paul C. Stoy ${ }^{6}$ and Julia H. Haggerty ${ }^{1}$
}

\begin{abstract}
Urgency and deliberateness are often at odds when executing conservation projects, especially as the scale and complexity of objectives increases. The pace of environmental degradation supports immediate and measurable action. However, best practices for adaptive governance and building resilient social-ecological systems call for more deliberate efforts and participatory processes, which can be slow. We explore conflicts between urgency and deliberateness and the potential for their reconciliation through a case study of the challenges of conserving native rangelands in North America's Northern Great Plains, an ecoregion targeted for global conservation initiatives. This region is undergoing a significant social-ecological transition, which underscores a need to rethink conservation strategies in light of the social-ecological system dynamics and potential future trajectories. Based on a structured narrative literature review process and iterative engagement with key regional stakeholders, we identify three interrelated factors critical to the system's future outcomes that illustrate system complexity as well as trade-offs between urgent and deliberate action and unilateral and multilateral approaches to conservation: (1) influences of land management on biodiversity, (2) economic restructuring and shifting land use priorities, and (3) changing climate and disturbance regimes. We identify key gaps in the literature for each factor and across the factors - an effort that informs our call for research and practice agendas that address uncertainty and complexity at regional scales through more inclusive and future-oriented approaches.
\end{abstract}

Key Words: adaptive governance; grassland conservation; land use change; scenario planning; stakeholder participation

\section{INTRODUCTION}

Urgency and deliberateness are often at odds in the implementation of conservation projects. Conservation practitioners face continual streams of statistics about the pace of environmental degradation that seem to mandate measurable action, often through immediate, unilateral habitat preservation, restoration, and remediation (Conference of Parties on Biodiversity 2016, Wilson 2016). At the same time, an established body of literature on complex social-ecological system (SES) dynamics finds that managing for resilience in the face of intractable, complex (i.e., "wicked") problems demands deliberate efforts to build local social and political support for conservation strategies (Folke et al. 2005, Berkes and Ross 2013, Arnold et al. 2017, Wyborn et al. 2019). Deliberate approaches may be necessary for situations where curbing biodiversity and ecosystem losses requires networks that can span public and private entities and broad spatial scales (Aycrigg et al. 2016). However, deliberate action is also resource- and time-intensive and can be challenged by issues inherent to SESs such as mismatched scales of governance and conflicting management trade-offs (Cumming et al. 2006, Cavender-Bares et al. 2015, DeFries and Nagendra 2017, Hruska et al. 2017). Equally important are issues of governance and legitimacy: Who has decision-making authority over what and where, and how do decision-makers generate broad support for conservation actions (Ingalls and Stedman 2016, Epstein et al. 2018)? While any action regarding conservation policy inherently involves intentionality, urgency-driven conservation actions can easily undermine the slower management strategies on which the ultimate success of complex conservation projects often rests. This tension reveals a need to reconcile urgent and deliberate conservation approaches (Sayer et al. 2013, Carter et al. 2017).

We conceptualize urgency and deliberateness following David Orr's (1996) articulation of fast versus slow knowledge. For Orr, fast knowledge focuses on solving problems linearly through technical fixes, power, and competition, while slow knowledge embraces complexity, resilience, and codependent and interconnected processes. In this synthesis, we define urgency as a philosophy about conservation strategy focused on immediate, often unilateral action and short-term gains that translate easily into "countable" metrics. Conversely, deliberateness describes slow processes and long-term outcomes achieved through multilateral problem-solving.

The problem of conserving one of the world's last remaining intact temperate grasslands heightens the importance of reconciling tensions between urgency and deliberateness. The conservation community largely overlooked temperate grasslands for the better part of the 20th century (Henwood 2010). However, in recent times, widespread habitat degradation and loss, coupled with increasing pressures from cultivation and impacts of climate change, have prompted fears over the future of native grassland systems, and calls for "urgent action...to protect and maintain the [social and ecological] services they provide..."(Conference of Parties on Biodiversity 2016). Grasslands represent the world's most heavily developed and altered biome and are also the most underrepresented ecosystem in protected areas worldwide (Henwood 2008). The conservation of grasslands necessitates a

${ }^{1}$ Department of Earth Sciences, Montana State University, Bozeman, MT, ${ }^{2}$ US Geological Survey, Northern Rocky Mountain Science Center, Bozeman, MT, ${ }^{3}$ Department of Land Resources and Environmental Sciences, Montana State University, Bozeman, MT, ${ }^{4}$ Department of Microbiology and Immunology, Montana State University, Bozeman, MT, ${ }^{5}$ Department of Animal and Range Sciences, Montana State University, Bozeman, MT, ${ }^{6}$ Department of Biological Systems Engineering, University of Wisconsin-Madison, Madison, WI 
reckoning with the social and economic systems that are dependent on them-and a corresponding social-ecological approach.

We highlight these issues through a case study of a subregion of North America's Northern Great Plains ecoregion that has become a focal point for conflicting conservation agendas. Specifically, we present a description of system dynamics in an SES comprising more than 6 million hectares in central Montana, USA, where expanses of intact native grass and sagebrush-steppe ecosystems have attracted global conservation attention. A challenge for enhancing conservation in the region is the landscape's complicated ownership profile, which includes multiple public land agencies and substantial private ownership. This pattern limits the ability to realize conservation goals at scale without coordinated approaches. Our approach is to study system dynamics through a narrative review of peer-reviewed literature and to evaluate the state of knowledge against the existing social and political landscape of conservation action. The study region centers on a core area of 525,000 hectares of federally protected lands adjoining national wildlife refuge and national monument lands. It is surrounded by a mosaic of publicly and privately owned rangelands. Because our geography of interest includes more than just grassland ecosystems, we use an encompassing term, "rangelands," to describe the region's biogeography (Dixon et al. 2014, Sayre 2017). The refuge and the region's cultural history inform its colloquial name and the shorthand we use here - the CMR region - to refer to the area in and around the Charles M. Russell National Wildlife Refuge (Fig. 1). A recent announcement by the National Geographic Society (2020) that designated the CMR region as one of its focal geographies in its global "Last Wild Places" campaign demonstrates the area's international conservation significance. Though several private, NGO, state, and federal conservation initiatives seek to conserve native rangelands and improve their ecological condition, a global effort to halt grassland degradation has motivated a set of regional conservation strategies that advocate for unilateral approaches and urgent action.

In the following sections, we describe how global and regional interest in grassland conservation has shaped the dominant conservation strategies currently playing out in the CMR region. Next, we report findings from a narrative review of system dynamics, an exercise that demonstrates uncertainty in several SES trajectories in the CMR region. These uncertainties prompt a discussion of whether and how urgent and deliberate conservation approaches can realize conservation goals for the region. Ultimately, we argue that a research and practice agenda united around trust-building, and the empowerment of regional stakeholders is key to supporting the CMR region's uncertain social-ecological future and developing conservation objectives that can succeed and endure.

\section{PRIORITY LANDSCAPES AND STRATEGIES FOR RANGELAND CONSERVATION}

\section{Locating the Northern Great Plains in the international} grasslands conservation imperative

"A sense of urgency" has accompanied the global grassland conservation movement since its inception (Henwood 2008:1). An early moment of recognition for grasslands' imperiled state emerged in 1996 when the World Commission on Protected Areas created the Grasslands Protected Area Task Force. Announcing grassland conservation as an "urgent task," the Task Force sought to "catalyze action" and "adopted increasing the level of protection for temperate grasslands as its immediate priority" (Henwood 2010:8). In 1998, the World Wildlife Fund (WWF) brought additional attention to the plight of native rangelands as part of its Global 200 campaign and warned that "the widespread destruction of the Earth's biodiversity occurring today must be matched by a response at least an order of magnitude greater than currently exists" (Olson and Dinerstein 2002:218). In 2008, the signing of The Hohhot Declaration, a global declaration advocating for the promotion of grassland protected areas, accompanied the creation of the Temperate Grasslands Conservation Initiative and the designation of priority conservation landscapes. Four landscapes noted for their conservation potential and the opportunity to restore intact grasslands at large scales emerged from the analysis: the Daurian steppe; the Patagonian steppe, the Kazakh steppe; and the Northern Great Plains.

Fig. 1. Study area (sources: Montana State Library Clearinghouse, U.S. Geological Survey, U.S. Census Bureau, Environmental Protecion Agency). Our designation of the CMR region uses the socio-political boundary of counties surrounding the Charles M. Russell (CMR) National Wildlife Refuge (NWR): Fergus, Valley, Blaine, Petroleum, Garfield, and Phillips Counties. Public lands managed as part of the Charles M. Russell Complex include UL Bend NWR, which is separately designated but managed under the auspices of the CMR NWR (USFWS 2012).

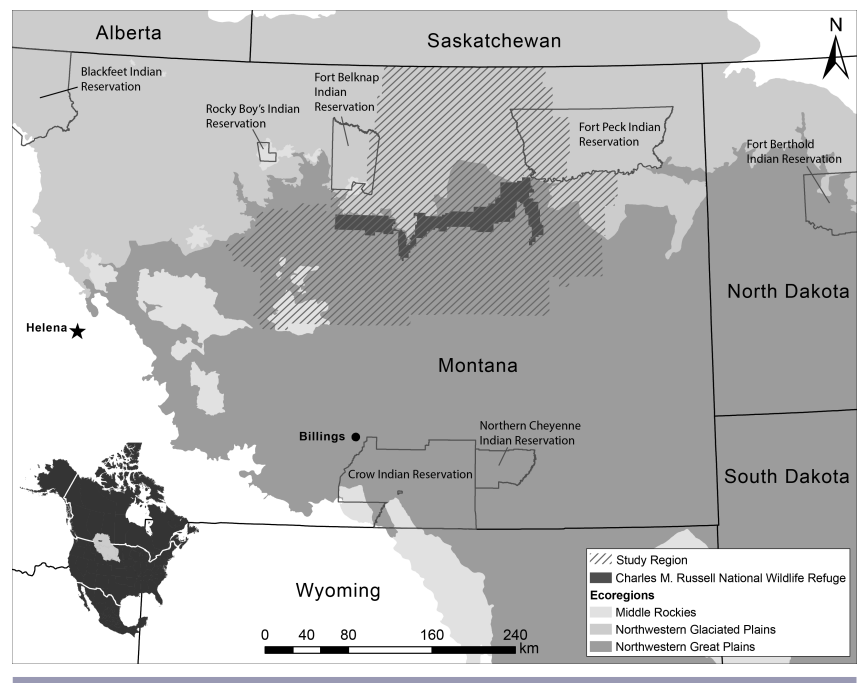

Encompassing an area about one and half times the size of California, or nearly 650,000 square kilometers, the Northern Great Plains includes portions of five U.S. states and two Canadian provinces. Though the Northern Great Plains have attracted scholarly attention throughout the 20th century (Kraenzel 1966), it was a landmark paper in 1987 by demographers Deborah and Frank Popper that thrust the region into the conservation planning spotlight (Popper and Popper 1987). In it, the Poppers proposed "the Buffalo Commons," a 
large-scale restoration and conservation development agenda. While initial efforts to establish a Buffalo Commons faltered, regional conservation advocates believed that a version of the Poppers' proposal was feasible in select portions of the Northern Great Plains, most notably, the CMR region (Mason 2011).

The CMR region straddles the Northwestern Great Plains and the Northwestern Glaciated Plains ecoregions and contains interspersed "mountain islands" of the Middle Rockies ecoregion (Omernik 1987, McMahon et al. 2001). The CMR region's variable continental climate and geomorphology support shortgrass prairie on the glaciated plains in the northern portions of the region (i.e., north of the Missouri River) and a mix of woodlands, shrublands, and grasslands south of the Missouri River (Rosenberg 1987, Epstein et al. 1996). The resulting suite of habitats supports numerous obligate and migratory species and has earned the region (including the Great Plains more generally) its moniker as the American Serengeti (Flores 2016). The CMR region contains the ancestral territory of multiple indigenous and First Nations groups and includes the current territory of the Fort Peck and Fort Belknap Indian Reservations. Livestock production has been the predominant land use and economic driver in the CMR region since the late 19th century. Despite episodic expansions of crop production and oil and gas development within the study area, intact rangeland vegetation persists across a substantial portion of the area, in part because the region's aridity and marginal soil quality best support rangebased land uses like livestock production (Alwin 1981, Wishart 2006, Preston and Kim 2016). Six counties surround the Charles M. Russell National Wildlife Refuge (CMR NWR), the region's major public land complex, and are invested in the refuge's natural resource management policies (CMRCWG 2020). We use this socioeconomic designation to bound the CMR region as an SES (Fig. 1).

\section{Ecoregional planning and the emergence of the Charles $M$.} Russell National Wildlife Refuge region's global importance The emergence of the CMR region as a late 20th century priority conservation target within the Northern Great Plains is intertwined with the evolution of ecoregional planning in conservation practice. United States federal land management agencies initiated ecoregional planning in the 1970 s as a means of achieving "quality land management" through a classification of "lands according to their capabilities and availability to produce goods and services in a balanced national program" (Bailey 1980:77). This approach reflected a growing interest in using what would now be recognized as land system science to identify and prioritize conservation needs (Turner et al. 2007).

In subsequent decades, conservation organizations and scientists expanded approaches that linked strategic assessments and prioritization processes with digital spatial analysis tools. When The Nature Conservancy (TNC) applied ecoregional planning to a suite of 116 sites across what it called the Northern Great Plains Steppe Ecoregion, the resulting analysis assigned highest priority status to the "Montana Glaciated Plains," an area overlapping the northern half of the CMR region. This status made the site one among nine of the 116 to receive the report's highest priority ranking (Northern Great Plains Steppe Ecoregional Conservation Team 1999). The 1999 TNC assessment derived conservation importance through a matrix that plotted ratings of "threat urgency" against "biodiversity significance" - a reminder that urgency has consistently informed conservation planning in the region. This area's biodiversity significance stems primarily from the presence of native grassland assemblages, whereas land uses like crop cultivation and energy development have altered much of the rest of the Northern Great Plains (Lark et al. 2015, Hendrickson et al. 2019).

A second ecoregional assessment soon followed TNC's 1999 study. This latter effort codified the rationale for a conservation strategy that embraced the CMR region as a unit. Published in 2004 with the title Ocean of Grass: A Conservation Assessment for the Northern Great Plains (hereafter Ocean of Grass), the report sought to integrate a new emphasis (in conservation science) on large-scale processes with the endemic biodiversity priorities of TNC's earlier approach (Forrest et al. 2004:95). In addition to evaluating the potential for in-migration of predators and the restoration of migratory bison herds in the Northern Great Plains, Ocean of Grass was also the first regional assessment to map social attributes of the landscape - population density and rate of population decline - and consider them as factors for site prioritization. A further distinguishing feature of the plan was its genesis within a network of conservation organizations linked across local, regional, and international scales, called the Northern Plains Conservation Network, with the WWF at the helm. Through a synthetic analysis of hundreds of layers of landscape attributes, Ocean of Grass produced "Ten Potential Core Areas for Conservation" throughout the Northern Great Plains. The Core Areas were selected through indices of "Biodiversity Importance" and "Restorability:" one was the area designated by TNC as Montana Glaciated Plains; another was a large rangeland area directly to the south, which the report called "The Big Open."

The 1999 and 2004 ecoregional assessments amplified the global conservation significance of the CMR region within the broader framework of grasslands conservation. In each report, the region's chief significance lay in the amount of native habitat it offered to threatened and endangered species relative to other more highly disturbed areas of the Northern Great Plains. Ocean of Grass also emphasized the potential for the region to host substantial restoration of habitat and species, particularly the American bison. In this way, Ocean of Grass carried elements of the Buffalo Commons proposal of the 1980 s into a 21 st century conservation agenda for the region. These factors motivated strong consensus among environmental scientists and landscape planners that the broader CMR region represented a global biodiversity hot spot in urgent need of conservation action.

\section{Modern manifestations of urgency and deliberateness in the Charles M. Russell National Wildlife Refuge region}

Today, many public and private conservation efforts in the CMR region continue to reflect the prioritization of grassland conservation. For example, management of the CMR complex strives to meet wildlife management objectives through limited public livestock grazing and prescribed burning strategies that the National Wildlife Refuge managers believe will improve rangeland quality and wildlife habit (U.S. Fish and Wildlife Service 2012). More broadly, Bureau of Land Management lands around the refuge comprise a mix of land use priorities ranging from Sage Grouse and grassland bird habitat preservation to 
multiple use. Concurrently, state government, NGO, and private actors work to incentivize stewardship and conservation practices on private land through grant rewards and funding, technical training, and cost-share programs.

Perhaps the strongest reflection of the urgency ethos in the CMR region is a private conservation project called the American Prairie Reserve (APR). It aims to be "the largest nature reserve in the continental United States" and has been cited by National Geographic as "one of the most ambitious conservation projects in American history" (Treinish 2013). The APR targets and purchases private properties with high conservation potential and access to public land grazing allotments (Nordhaus 2020). Once acquired, APR manages their holdings as a public reserve with the primary goal of enhancing wildlife habitat by reducing cattle grazing and/or switching to bison grazing.

As a key node in the lineage linking the Ocean of Grass report and the growing sense of urgency in grassland conservation, the APR formed in 2001 in response to recommendations from the WWF that "an independent entity, capable of focusing all of its time and resources on the preservation of Montana's Northern Great Plains, would be the best vehicle through which to initiate a large-scale conservation effort" (American Prairie Reserve 2016b). In this way, the urgency conveyed in Ocean of Grass motivated both the advent of the APR and its market-based strategy of grassland property acquisition. Supported by extensive fundraising efforts, including from wealthy individuals from the United States and Europe, the APR has expanded quickly, acquiring 162,000 hectares since 2004 (Bullinger 2017, Davenport 2018). The APR believes that its market-based approach offers distinct advantages over the existing set of conservation strategies: "we (the APR) can make and carry out decisions on our private lands that improve habitat and encourage public access much quicker [sic] than a public agency can. We are also free to focus our land management decisions exclusively on benefiting wildlife and the public's enjoyment of it" (American Prairie Reserve 2016a).

\section{SOCIAL-ECOLOGICAL SYSTEM DYNAMICS IN THE CHARLES M. RUSSELL NATIONAL WILDLIFE REFUGE REGION: KEY DRIVERS, INTERACTIONS, AND FEEDBACKS}

The perception of managerial nimbleness, especially compared with government-led conservation projects, has made private protected areas a preferred tool for addressing the issue of rapid biodiversity loss, including the urgent needs of grassland conservation (Brockington et al. 2012, Jenkins et al. 2015, Drescher and Brenner 2018). Yet, limitations exist. For example, when local communities perceive efforts to protect lands through large private protected areas (primarily by "outsiders" or out-ofstate individuals) as a type of fortress-style or top-down conservation model, social conflict and local pushback often ensues and may even threaten the long-term viability of the project's conservation agenda (Holmes 2014). Furthermore, the rapid onset of global change challenges the traditional boundaries of protected area approaches (Hannah et al. 2007). Here, the fundamental tension between urgency and deliberateness emerges. While urgency-motivated projects can work quickly to accomplish conservation results, they may suffer from a lack of broader social and ecological context and miss opportunities to become resilient to future shocks and systemwide changes (Cumming et al. 2015).

To view critical conservation areas more holistically, conservation scientists and managers are increasingly embracing SES perspectives (Cumming and Allen 2017). As part of this approach, actors use adaptive governance, a framework for managing complex system dynamics and resilience thinking, which "assumes and manages for change, rather than against [it]" (Gunderson and Light 2006:325). Adaptive governance approaches to managing critical conservation landscapes like the CMR region advocate for participation and involvement from a range of actors and stakeholders through social learning and public participation and conservation actions across multiple private and public partners (Folke 2009, Huitema et al. 2009, Chaffin et al. 2014, 2016). Adaptive governance thus exemplifies more deliberate approaches to conservation policy and planning and the preferred framework for addressing complexity, multiple stable states, thresholds, and transitions in SESs. These processes demand intentional trust- and coalition-building and long-term engagement and investment in collaborative decision-making. This makes them inherently slow, resource-intensive, and difficult to incorporate into conservation projects that prioritize speed and conventional ideas about economic efficiency (Stringer et al. 2006, Nie and Metcalf 2016, Schoonover et al. 2019).

To further unpack the tension between urgency and deliberateness in the CMR region context, we adopt a resilience assessment approach to better understand our study site's current and potential future social-ecological dynamics (Walker et al. 2006). In resilience assessments and related methods, a first step to understanding system trajectories is to characterize a system's state and relevant drivers (O'Connell et al. 2015). This initial effort clarifies potential issues and trade-offs and identifies opportunities for adaptive management (Allen et al. 2017) or transformation of the system to more desirable states (Chaffin et al. 2016, Walker and Leyshon 2017). We use a narrative review process to identify relevant findings such as key drivers for each issue, interrelationships between drivers, trade-offs between management approaches, social-ecological traps, and potential scale mismatches.

\section{Approach: social-ecological system assessment and narrative review}

Our approach to understand the socioeconomic, ecological, and biophysical contexts of land management strategies in the study region and to identify stakeholder perceptions about conservation imperatives, threats, and challenges took place over two years through multiple avenues. First, to identify key drivers in the CMR region SES, we collected local and expert stakeholder input through field trips, workshops, and a research seminar series. We used the discussions, notes, peer-reviewed literature referenced, and our prior research in the region to develop a conceptual SES model to identify values and drivers at regional and national scales (Collins et al. 2011, O'Connell et al. 2015). From this model, we identified three prominent issues - changing land use patterns, changing climate and disturbance regimes, and the influence of land management practices on biodiversity-where additional information was needed to characterize uncertainty, address research gaps, and represent areas of potential trade-offs. To outline and address these issues, we conducted a narrative 
literature review. Narrative literature reviews are "exploratory reviews that seek to synthesize insights from a variety of perspectives and disciplines, or areas where insufficient data exists to conduct a systematic review or meta-analysis" (Sovacool et al. 2018:23). Both circumstances describe the context of this review. Rather than comprehensive, we aim to be illustrative by focusing on interrelationships and commonalities between the three issues.

\section{Social-ecological system dynamics relevant to conservation in the Charles M. Russell National Wildlife Refuge region}

Because conservation actors value the CMR region for its extensive native habitat and potential to support native biodiversity, we explore the key feedbacks in the SES that influence these attributes. Accordingly, the following synthesis focuses on three system dynamics: (1) the relationship between land management strategies and biodiversity in rangelands, (2) the influence of markets and policy on ownership and land use patterns and conservation practice in the region, and (3) the relationship between climate, disturbance, and native vegetation dynamics. For each issue independently, and then in combination, we discuss how the identified time frames, geographic scales, and uncertainties underscore the tensions between urgent and deliberate approaches and unilateral and multilateral actions for conservation in the region.

\section{Rangeland management and land use feedbacks to wildlife diversity}

We focus our review of biodiversity and land use and management on grassland birds and prairie grouse. Birds provide critical ecosystem services (Şekerciŏglu et al. 2004, Whelan et al. 2008) and are considered reliable surrogates for biodiversity because they are sensitive to changing habitats (see Dettenmaier et al. 2017, Golding and Drietz 2017). A steep drop in bird diversity, noted in select sites across the study area, signals a decline in regional biodiversity, likely from the conversion of native grassland due to land conversion (e.g., "plow up" and urbanization) (Sieg et al. 1999, Sauer and Link 2011, Lipsey and Naugle 2017, Duchardt et al. 2018, Correll et al. 2019, Hendrickson et al. 2019, Rosenzweig and Schipanski 2019). For these reasons, conservation advocates consider the preservation of native prairie and the prevention of widespread conversion as critical to maintaining biodiversity across the CMR region (Smith et al. 2016, Hendrickson et al. 2019). Research also supports, where possible, reclaiming areas converted from croplands back into grassland and shrubland habitats to benefit certain bird species (Haroldson et al. 2006). However, uncertainties about the efficacy and long time frames necessary to restore plant communities in semiarid environments underscore the importance (urgency) of avoiding land conversion in the first place (Hendrickson et al. 2019).

Given that remaining grassland bird habitat often occurs in working landscapes, a feedback of interest to ecologists involves the response of grassland birds and prairie grouse populations to different rangeland management systems - an area where there is considerable scientific uncertainty. Recently, applied research has suggested that the conventional approach of reducing spatial and temporal variability in rangeland conditions through managing the distribution and intensity of grazing may benefit some species while selecting against others (Toombs et al. 2010), which has led to proposals to "manage for heterogeneity" as an alternative. This approach advocates for strategic combinations of human interventions through herbivory and fire at broad scales to promote the diverse habitat types necessary to maximize biodiversity outcomes in rangeland systems (Fuhlendorf and Engle 2004, Fuhlendorf et al. 2017). However, more research is needed to evaluate the applicability of specific management approaches across the variable entirety of the Great Plains (Augustine and Derner 2015). In regions adjacent to our SES, increasing landscape heterogeneity improved outcomes for some grassland birds, although positive responses were species-specific, and differences in the overall community were minimal (Golding and Dreitz 2017). While grassland bird species in the region exhibit variability in habitat use (Pulliam et al. 2020), heterogeneity-based management practices have little to no effect on variables of species viability for grassland birds and prairie grouse in the CMR region (Smith et al. 2016, 2018, Milligan et al. 2020).

Research conducted in the region suggests that variation within larger landscape-scale factors, such as precipitation and soil productivity, has more influence on grassland and shrubland bird species occurrence than differences in particular land management approaches (Doherty et al. 2010, Lipsey and Naugle 2017, Vold et al. 2019, Smith et al. 2020). These findings underscore a central challenge in managing biodiversity across large landscapes where variability is a defining characteristic of the ecosystem (Sayre 2017), as the outcomes of any single management prescription will vary accordingly. Thus, conserving biodiversity in rangelands requires careful consideration of management practices and habitat availability at multiple spatial scales, coordination across land ownership boundaries, a variety of land management techniques, and a commitment to ongoing, iterative learning by multiple stakeholders (Allen et al. 2017, Sliwinski et al. 2018). While individual entities may desire urgent management intervention, the ecological studies we reviewed emphasize the importance of coordinating management at a broader scale through deliberate approaches that can incorporate the landscape heterogeneity needed to meet biodiversity objectives (Wilmer et al. 2018).

\section{Markets, policy, and persistence or disruption of a range and farm land use regime}

Currently, diverse and interacting market and policy forces are driving new and sometimes conflicting land use outcomes, resulting in uncertainty about the future of the range and farm land use regimes in the CMR region. For example, some policies encourage cropland expansion and intensification of crop agriculture and livestock production. Lark et al. (2015) show that federal energy and Farm Bill policies incentivize the conversion of native grasslands in the Northern Great Plains through the expansion of bioenergy crops and wheat production. Land conversion has been a strong contributor to an urgency imperative in conservation practice. At the scale of the CMR region, however, the evidence is not straightforward. The region features counties that simultaneously show high rates of recent conversion in the Northern Great Plains, as well as reports of grassland expansion and low risk of future conversion in probabilistic modeling (Auch et al. 2011, World Wildlife Fund 2018, Olimb and Robinson 2019).

The intensification and expansion of agriculture associated with some policies contrast with "deintensification" encouraged by 
state and federal public policies and private entities. The Conservation Reserve Program, federal conservation compliance programs, and national and state conservation initiatives encourage conservation practices by offering financial and technical assistance. These programs work to withdraw marginal land from production and increase wildlife habitat on private property (Steiner 1990, Lawrence et al. 2018, Montana Sage Grouse Habitat Conservation Program 2020). Livestock assistance programs also have encouraged a type of intensification through the construction of water infrastructure as a range- and resource-conservation measure (Stubbs 2010, 2016). However, it is still unknown whether the expansion of water infrastructure supports or constrains the abilities of range-based economies to adapt to changing water resource conditions at the operational or watershed scale (Ward and Pulido-Velazquez 2008, Batchelor et al. 2014). Additionally, relevant for our study region will be financial incentives for managing rangelands as global carbon sinks. Though "carbon farming" is currently more theoretical than operational (Dolan et al. 2020), future policy prescriptions for sequestering soil carbon could incentivize practices related to restoring cultivated ground and the provisioning of ecosystem services associated with building carbon stocks (Lal et al. 2013, Lal 2014, Western Sustainability Exchange 2019). Because these policies are characterized by an emphasis on multistakeholder coordination and novelty, their outcomes for biodiversity are not well documented, which emphasizes the need for monitoring and evaluation (Allen et al. 2017).

Lastly, policy and market forces have feedbacks with conservation practice in the region in ways that emphasize the importance of multilateral coordination. For example, despite its preference for market-based solutions, APR's conservation approach is highly sensitive to nonmarket forces. Changes to the policy and political environments affect the NGO's actions and the actions of neighboring landowners, including federal and state land management agencies, a characteristic well demonstrated in an ongoing conflict about the Reserve's bison management strategies (American Prairie Reserve and Bureau of Land Management 2019, Associated Press 2019). In addition to conflicting land use policies and politics, a new set of multifunctional values and market opportunities drives the increased prevalence of nonlocal ownership. The transfer of historical cattle ranches into hunting camps and recreation properties makes future conservation opportunities highly uncertain (Norman C. Wheeler \& Associates 2019, Turkewitz 2019). At the same time, and in other rangeland contexts, multifunctional transitions have accompanied increases in residential and infrastructure development, both of which are recognized challenges for conservation action (Reeves et al. 2018). Taken as a whole, the policy and market landscape affecting conservation practice in the CMR region reveals inconsistencies as well as a generalizable uncertainty about their interactive effects - how one set of approaches and policies triggers and results in linked changes to land use decisions. This observation, and perceptions of certainty, emphasize the interdependence of conservation strategies, and raise questions about choosing urgency at the cost of coordination and deliberation.

Influence of climate and disturbance on rangeland vegetation structure and productivity

Warming temperatures, greater precipitation, increased $\mathrm{CO}_{2}$ levels, and altered disturbance regimes have led to increases in vegetation productivity and woody plant abundance across the Northern Great Plains. Recent documentation of these changes includes sustained productivity increases across $\sim 20 \%$ of the Northern Great Plains (Brookshire et al. 2020), "moderate or substantial" woody plant expansion across much of the region (Symstad and Leis 2017), and increased precipitation during spring and summer (Bromley et al. 2020). The expansion of woody vegetation, and its associated increases in vegetation productivity, has some potential benefits in the short term, such as carbon storage. However, woody plant expansion has noted negative consequences for grassland biodiversity (Ratajczak et al. 2012), and can lead to increased strains on soil nutrient pools, with downstream effects for long-term nutrient availability (Brookshire et al. 2020). Projected precipitation and temperature increases (Whitlock et al. 2017), coupled with ongoing and legacy effects of altered disturbance regimes (e.g., drought, fire, and herbivory), are likely to support continued widespread vegetation shifts. A high degree of uncertainty surrounding future change signals the urgent problem of maintaining contemporary rangeland vegetation. This complicated and moving baseline indicates a role for more deliberate action.

Contemporary rangeland vegetation in the Northern Great Plains is maintained largely via interactions between two key disturbances, namely fire and herbivory (Umbanhowar 1996, Brown and Sieg 1999, Fuhlendorf et al. 2009, Williams et al. 2009, Grimm et al. 2011). Fire in rangelands alters the abundance, form, and distribution of nutrients among plants and soils, thus creating patches of nutritious forage with high crude protein concentrations (Wan et al. 2001, Briggs et al. 2002, Zedler 2007, Powell et al. 2018). Herbivory can influence vegetation productivity by promoting frequent plant turnover, facilitating nutrient cycling, and modifying fuel characteristics and fire behavior (Hempson et al. 2017). For instance, low- to moderateintensity grazing can limit and fragment fine fuel loads, resulting in more frequent but less intense fires, and favoring the dominance and persistence of grassland vegetation. Conversely, highintensity grazing may encourage the expansion of woody plants by removing herbaceous competitors and suppressing burning, which can lead to infrequent but severe wildfire (Madany and West 1983, Bachelet et al. 2000, Sinclair et al. 2007). Both fire and grazing interact to maintain grassland vegetation and regulate the expansion of woody plants (Fig. 2) (Briggs et al. 2002, Zedler 2007, Fuhlendorf et al. 2009). Individual land managers can impact the herbaceous-woody balance through intentional management actions. However, the potential for landscape-level change due to climatic and disturbance drivers demonstrates a need for deliberate and broad coordination to stave off undesirable cross-boundary transformations.

Likewise, adapting to the broad-scale yet highly variable (and uncertain) impacts of changing climate will require deliberate and flexible approaches. In general, low mean annual precipitation (Fig. 2) (Scholtz et al. 2018, Breshears et al. 2005, Collins et al. 2011, Twidwell et al. 2014, Archer et al. 2017) and periodic drought (Stockton and Meko 1983, Laird et al. 1996, Clark et al. 2002) are key drivers of grassland persistence. These characteristics provide the requisite competitive advantages that allow grasses adapted to semiarid environments to dominate over less tolerant woody vegetation. Yet, climate models project that future precipitation will increase (Whitlock et al. 2017, Gerken et al. 2018). Such changes may accelerate current woody plant 
expansion but also hinge on the variability, timing, and duration of future precipitation events. Additionally, higher concentrations of atmospheric $\mathrm{CO}_{2}$ may add additional complexity to future change adaptation by providing advantages to young trees but simultaneously increasing grass and forb productivity (Bond and Midgley 2000, Reeves et al. 2014). Ecosystem-scale response to persistent and slow change is challenging to predict because unexpected threshold responses might exist for vegetation structure, fire regimes, and biogeochemical dynamics (Ives and Carpenter 2007). In sum, this literature suggests that planning for conservation action in the CMR region requires an acute understanding of these changes, particularly their variability, to frame how ecosystem baseline conditions will evolve and change in the years ahead.

Fig. 2. Conceptual overview of select drivers (inside arrow) impacting vegetation shifts between rangeland, woodland, and forest. Spatial and temporal changes in mean annual precipitation theoretically dictate the maximum abundance of woody vegetation, yet other factors interact to influence where the vegetation regime can shift. The solid line displays a threshold between rangeland and woodland at a higher point in the precipitation gradient due to interactions between moderate grazing, fire, variable precipitation, and lower $\mathrm{CO}_{2}$. Conversely, transition to woodland or forest may occur more rapidly and at lower mean annual precipitation given higher atmospheric $\mathrm{CO}_{2}$, less variable precipitation, fire suppression, and/or overgrazing (dashed lines).

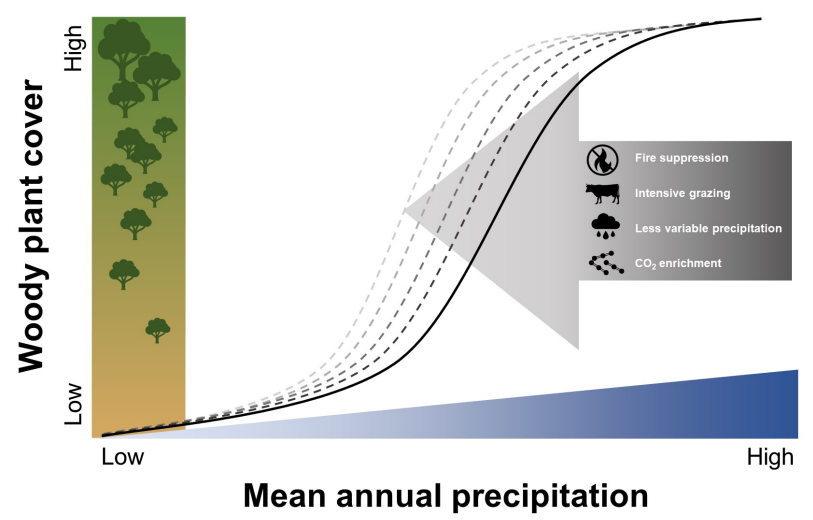

\section{CONTEXTUALIZING INTERCONNECTIONS AND OPEN QUESTIONS FROM THE CHARLES M. RUSSELL NATIONAL WILDLIFE REFUGE SOCIAL-ECOLOGICAL SYSTEM}

\section{Navigating the certain uncertainties}

Our review highlights meaningful, convergent interactions among rangeland conservation initiatives, economies and social systems, and ecosystem dynamics, as well as the many uncertainties related to future climatic conditions and market forces. We discuss the relevant outcomes for conservation projects and biodiversity management as means to consider urgent versus deliberate conservation approaches and meaningful issues to be addressed through adaptive governance approaches.
While research on crop conversion trade-offs indicates that incentives from national policy promote conversion for some landowners, it is not clear whether those same factors drive conversion for the CMR region. Beyond the threats of conversion, projected climate dynamics will likely shift the structure and function of grassland vegetation in our study region, and if coupled with continued fire suppression and unsustainable grazing, will alter the composition, continuity, and availability of fuels in the CMR region. Likewise, the projected variability in yearly weather patterns will interact with market forces to change the calculus for landowners choosing between sustainable economic approaches and the profitability of converting marginal land (Costanza et al. 1998, Stoy et al. 2018, Sanderson et al. 2020). Together, these interactions underscore a need for further socialecological research to disentangle how climate, fire, and grazing interact so that managers can anticipate and prepare for future change (Taylor et al. 2014).

Our review underscores the inherent complexity associated with managing rangeland SESs to enhance biodiversity outcomes (Hruska et al. 2017). The literature emphasizes that because management approaches for biodiversity are often dependent on vegetation productivity and yearly weather, no single strategy is sufficient to achieve landscape-scale biodiversity goals (Lipsey and Naugle 2017). Instead, our review suggests that enhancing biodiversity in the CMR region SES requires collaborative research-management approaches to provide the information needed for adaptive governance. Rather than single entities approaching conservation independently on individual parcels, we recommend a networked design in which researchers and land managers develop shared databases and aggregate site- or property-level data to better support multiscalar and interscalar biodiversity research (Wilmer et al. 2018).

Our review also notes an important socio-political reaction to approaches perceived as urgent and singular, such as APR's bison restoration program (Bullinger 2017, American Prairie Reserve and Bureau of Land Management 2019), where feedbacks to land use policy raise questions about the long-term viability and social license of certain types of conservation strategies (Kendal and Ford 2018). Urgency-driven conservation initiatives can generate significant financial capital and organizational capacity to initiate focused and bold action within a single entity. However, they may engender secondary effects with downstream consequences for land ownership, land use, and biodiversity, and ultimately undercut conservation goals for the broader landscape. In managing for an unknown future, practices will need to recognize multiple human factors. For example, human communities have been involved intimately in the production of the "historical" Northern Great Plains and have influenced vegetation dynamics and landscape heterogeneity, especially through the use of fire, for thousands of years (Marlon et al. 2013, Taylor et al. 2014, Roos et al. 2018). Mounting evidence from other imperiled biomes and conservation hot spots emphasizes the current role that communities play in stewarding natural resources and managing biodiversity, and effectively highlights that "healthy ecosystems and community well-being are interdependent" (Gray et al. 2001:21, Tauli-Corpuz et al. 2020). Other research describes how engaging in ecological restoration can increase emotional wellbeing for individuals and communities (Jordan 2003, Haggerty et al. 2018). The links between rural communities and biodiversity point to important questions related to legitimacy and governance 
(e.g., who or what has "authority" to enact conservation policies [Ingalls and Stedman 2016]), as well as unrealized opportunities for the role of local communities in conservation in the region. Future research attention to the nexus of social, ecological, and political dynamics is critical to advancing equity alongside conservation goals. In the case of the CMR, this focus suggests an unanswered but important question for regional conservation practice: How can local communities be partners in large-scale conservation initiatives and share in the prosperity that can come with the restoration activities associated with global conservation status (Belsky 2011)?

\section{Reconciling urgency and deliberateness: toward a resilience rangeland conservation praxis}

Our SES assessment of the CMR region illustrates how interactions and feedbacks between and within key system dynamics alter the social-ecological template of our study area and the Northern Great Plains more generally. Most importantly, a key finding from our literature review is that the complexity and interconnections among these multiple drivers of socialecological change make future trajectories of the native rangeland system and the conservation projects working to restore and conserve them highly uncertain (Stoy et al. 2018). Meeting biodiversity and sustainability goals in the context of uncertain social-ecological trajectories requires more than the preservation or restoration of current landscapes. Resource managers and landowners will need to adapt to changing climate regimes and create adaptive governance strategies that anticipate and respond to dynamic conditions over broad geographies. In addition, drivers of policy and climate at larger regional and national scales, along with the need for landscape-level management strategies for biodiversity, make it difficult for any individuals or single entities to enact system-wide change. Conservation programs at the federal, state, and local level also need to be coordinated to maximize effectiveness, be based in optimal locations, and share knowledge and resources. Urgency-driven conservation approaches are apt to move quickly yet do so at the expense of addressing uncertain social-ecological system trajectories. Meanwhile, deliberate approaches are better suited to address system dynamics comprehensively but come with risks; overengagement with complex system dynamics can lead to delayed management action, or worse, paralysis (Cumming et al. 2006, DeFries and Nagendra 2017) (Fig. 3). Other research on landscape-scale conservation suggests that creating the parameters of conservation success in the CMR region will take coordinated planning and management beyond the preserved core of the CMR region and must encompass multiple-use federal lands and a diverse set of private landowners (Grant and Quinn 2007, Bixler et al. 2016, Epstein et al. 2018). While the issues are urgent, addressing social-ecological uncertainty head-on provides opportunities to chart out appropriate adaptive governance strategies for long-term success.

New conservation approaches are necessary to support the resilience of the CMR region. Our review suggests that in addition to addressing the tension between urgency and deliberateness, conservation strategies will need to reckon with multiple unknowns related to future system trajectories. Another challenge will be to negotiate the diverging perspectives and orientations of all stakeholder groups in the region related to rangeland restoration and bison in particular. Here, ensuring that processes engage Native American communities and confront the historical and ongoing colonial legacies that are active in rangeland management debates is essential to creating more just and inclusive social-ecological futures (Whyte 2018, Buscher and Fletcher 2020).

Fig. 3. Illustration of a hypothetical balance for supporting success of a resilience-based approach to address complex problems in a social-ecological system. The vertical axis charts the level of collaboration within a conservation process. Success in conservation projects is often dependent on opportunities for trust building and ensuring public support for conservation actions. Research emphasizes that conservation initiatives should consider how they collaborate with and engage various stakeholders to maximize inclusion and prevent oversimplifying needs and objectives. The horizontal axis illustrates the level of process and system knowledge within a conservation approach. The literature suggests that processes should support prudent action but resist the tendency to delay until complete knowledge or control over all aspects of the system are known. Strategies that are either excessively urgent or excessively deliberate may fail to find a balance between these aspects and ultimately lead to undesired outcomes. To address the tension between urgency and deliberateness, our synthesis recommends that conservation projects engage in processes that address uncertainty, promote dialogue, and encourage inclusion. The location of this conservation "sweet spot" is unique to each situation and may require adjustments to build resilience in an effective and lasting way. Superscripts correspond to references that address the traps and potential pitfalls summarized (1: Cumming et al. 2006; 2: DeFries and Nagendra 2017; 3: Freeman et al. 2015; and 4: Sayer et al. 2013).

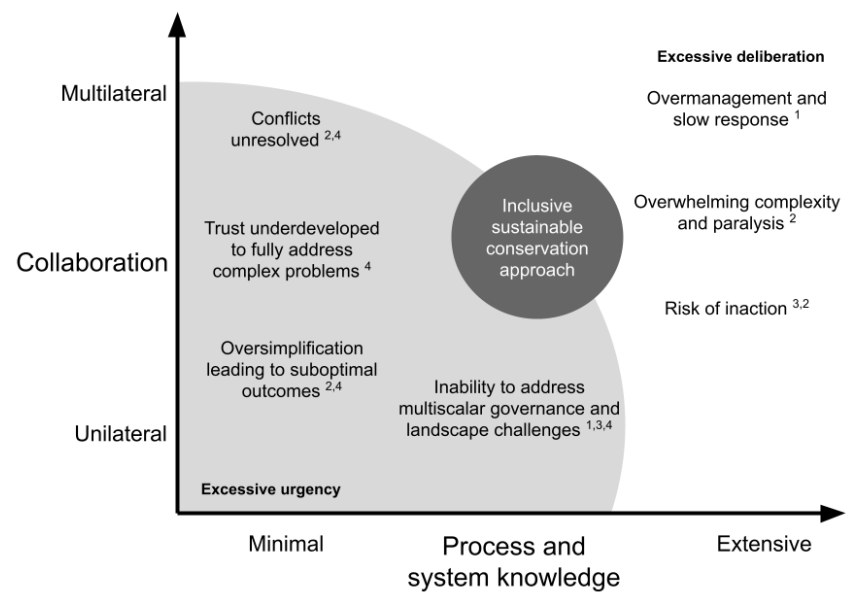

Specifically, the SES dynamics of the region suggest a need for participatory approaches that strategically engage with uncertainty and provide opportunities to develop coordinated dialogue, coalition-building across disparate groups, and social learning, and thus, advance some of the challenges associated with conservation strategies built within and deployed from individual silos (Talley et al. 2016, DeFries and Nagendra 2017, Knapp et al. 2017). One such approach is scenario planning. 
Multiple conservation planning processes have leveraged scenario planning (e.g., Oteros-Rozas et al. 2015), and in situations of high uncertainty and low controllability, scenario planning is a preferred approach for explicitly addressing many future socialecological changes by assessing how various system trajectories shift benefits and risks across the system (Peterson et al. 2003, Amer et al. 2013, Brugger et al. 2018). While the particularities of the CMR SES make scenario planning an apt approach for the region, conservation planning in other contexts may benefit from a different mix of adaptive governance approaches (Peterson et al. 2003).

By design, our engaged narrative review represents an essential step in building toward a participatory, multistakeholder process by identifying gaps in the literature relevant to SES stakeholders and science partners. These gaps, in turn, can inform a targeted research agenda to investigate interactions among climate, disturbance, biodiversity, land use, markets, and policy that lead to the refinement of potential future system trajectories. Iterative regional dialogues among stakeholders invested in the resilience of conservation practice in the CMR region can use future trajectories to address uncertainty by generating plausible future scenarios and potential responses. Engaging in a deliberative, organized process that explicitly deals with uncertainty and lack of individual control offers a counterbalance to participatory approaches that might otherwise lack a structured approach for managing complexity and uncertainty.

In addition to a set of basic and applied research needs, our synthesis highlights the potential in bringing the history of conservation policy and practice into engagement with SES dynamics. As our short history of grassland conservation in the CMR region details, a potent urgency logic emerged within a particular convergence of technological, economic, and political trajectories.

Future investigations of urgency versus deliberateness should question not only how conservation logics align (or not) with SES dynamics but how concepts such as urgency and deliberateness manifest particular environmental politics. Equally important are investigations into the spatial configurations of conservation logics: how particular ideas about conservation may motivate singular land use strategies (e.g., private protected areas) or seek to accommodate multiple values and land use practices related to biodiversity opportunities and the synergies among them. Approaching these types of questions requires coupling resilience thinking with theories of power and resource access and supporting multidisciplinary and transdisciplinary research that spans the social, ecological, and political (Ingalls and Stedman 2016, Stojanovic et al. 2016).

While understandably daunting to positivist epistemologies, the acknowledgment of mutability in core conservation concepts such as urgency, deliberateness, or uncertainty is more than just a (necessary) exercise in social construction. Such a framework also opens up exciting space for experimental approaches that privilege knowledge coproduction and social learning (Whatmore and Landström 2011). Well-facilitated engagements between oppositional stakeholders in the CMR that dissect the positionality and perspectives surrounding one group's "sense of urgency" or assumption of uncertainty might generate alternative ways of approaching the region's conservation needs and motivate the stewardship potential of collective action.

\section{CONCLUSION}

We used a case of rangeland conservation in the Charles $\mathrm{M}$. Russell National Wildlife Refuge region of central Montana, USA to illustrate the trade-offs implicit in enacting urgent conservation by drawing attention to the complexity and uncertainty inherent in social-ecological systems. Our goal is not to discount the dire and extreme nature of current ecological crises (Noss et al. 1995, Pecl et al. 2017). However, urgency-driven strategies will always, by design, enable some visions of the future at the expense of others. Because the longevity of conservation projects hinges on public support and buy-in, privileging shortterm gains over the collective future may undermine long-term conservation success (Bennett et al. 2019). Failing to recognize that privileged conservation logics and strategies derived from the broader political contexts that empower some approaches over others further undermines opportunities for collective and synergistic action (Fig. 3). Our challenge then, as conservation scientists and advocates, is to help reimagine conservation as an opportunity to support social-ecological thriving (Buscher and Fletcher 2020). Insights from our long-term engagement in the CMR region and narrative review indicate a role for basic science as a collaborative partner in rural development and conservation practice via adaptive governance approaches such as scenario planning. Beyond any specific methodology, however, our synthesis argues that grassland conservation would benefit from a new conservation praxis that takes the tenets of resilience seriously by developing processes that build latent capacity for diverse groups to collaborate. Only then can conservation strategies work to support biodiversity and social and economic well-being while also enabling the conditions necessary for managing uncertainty in the search for desirable social-ecological futures.

Responses to this article can be read online at: https://www.ecologyandsociety.org/issues/responses. php/12141

\section{Acknowledgments:}

This paper is a collaborative project of the Montana State University Grassland Resilience Working Group. This paper originates from a speaker series and field trips across central Montana organized by the authors of this manuscript. We thank Stephanie Ewing, Bill Milton, Quentin Kujala, Brett Olson, Matt Lavin, Andy Boyce, Caitlin Mitchell, Cliff Montagne, and Amy Webbink for their insightful discussions on social-ecological resilience. In addition, we thank Laura Nowlin, Reba Ahlgren, Andrew Horvath, Matt Comer, Skip Ahlgren, Diane Ahlgren, Dean Rogge, Hila Shamoon, and many others for sharing their diverse experiences and challenges with us in our work across central Montana. We thank Jackson Rose for creating the study area map and John Carlson and two anonymous referees for comments that improved this manuscript. Convenings and programming associated with the Grasslands Resilience Working Group were supported by the National Science Foundation under Grant No. 1832452 and Grant No. 1632810. Any use of trade, firm, or product names is for descriptive purposes only and does not imply endorsement by the $U$. S. Government. 


\section{Data Availability:}

No data or code were compiled as part of this project.

\section{LITERATURE CITED}

Allen, C. R., D. G. Angeler, J. J. Fontaine, A. S. Garmestani, N. M. Hart, K. L. Pope, and D. Twidwell. 2017. Adaptive management of rangeland systems. Pages 373-394 in D. D. Briske, editor. Rangeland systems: processes, management, and challenges. Springer International Publishing, Cham, Switzerland. https:// doi.org/10.1007/978-3-319-46709-2

Alwin, J. A. 1981. Jordan Country - a golden anniversary look. Annals of the Association of American Geographers 71(4):479-498. https://doi.org/10.1111/j.1467-8306.1981.tb01370.x

Amer, M., T. U. Daim, and A. Jetter. 2013. A review of scenario planning. Futures 46:23-40. https://doi.org/10.1016/j.futures.2012.10.003

American Prairie Reserve. 2016a. Our story. Bozeman, Montana, USA. [online] URL: https://www.americanprairie.org/our-story

American Prairie Reserve. 2016b. Building the reserve FAQs. Bozeman, Montana, USA. [online] URL: https://www. americanprairie.org/building-the-reserve-faqs

American Prairie Reserve and Bureau of Land Management. 2019. APR new grazing proposal. September 2019.

Archer, S. R., E. M. Andersen, K. I. Predick, S. Schwinning, R. J. Steidl, and S. R. Woods. 2017. Woody plant encroachment: causes and consequences. Pages 25-84 in D. D. Brisk, editor. Rangeland systems: processes, management, and challenges. Springer International Publishing, Cham, Switzerland. https:// doi.org/10.1007/978-3-319-46709-2

Arnold, C., H. Gosnell, M. Benson, and R. Craig. 2017. Crossinterdisciplinary insights into adaptive governance and resilience. Ecology and Society 22(4):14. https://doi.org/10.5751/ES-09734-220414

Associated Press. 2019. Huge nature reserve shrinks bison plan after pushback. U.S. News \& World Report, September 24, 2019. [online] URL: https://www.usnews.com/news/best-states/montana/ articles/2019-09-24/apnewsbreak-montana-reserve-cuts-bison-grazingrequest

Auch, R. F., K. L. Sayler, D. E. Napton, J. L. Taylor, and M. S. Brooks. 2011. Ecoregional differences in late-20th-century landuse and land-cover change in the US Northern Great Plains. Great Plains Research 21(2):231-243.

Augustine, D. J., and J. D. Derner. 2015. Patch burn grazing management in a semiarid grassland: consequences for pronghorn, plains prickly pear, and wind erosion. Rangeland Ecology \& Management 68(1):40-47. https://doi.org/10.1016/j. rama.2014.12.010

Aycrigg, J. L., C. Groves, J. A. Hilty, J. M. Scott, P. Beier, D. Boyce, D. Figg, H. Hamilton, G. Machlis, and K. Muller. 2016. Completing the system: opportunities and challenges for a national habitat conservation system. BioScience 66:774-784. https://doi.org/10.1093/biosci/biw090

Bachelet, D., J. M. Lenihan, C. Daly, and R. P. Neilson. 2000. Interactions between fire, grazing and climate change at Wind
Cave National Park, SD. Ecological Modelling 134(2-3):229-244. https://doi.org/10.1016/S0304-3800(00)00343-4

Bailey, R. G. 1980. Description of the ecoregions of the United States. Misc. Publication 1931. U.S. Department of Agriculture, Washington, D.C., USA.

Batchelor, C., V. Ratna Reddy, C. Linstead, M. Dhar, S. Roy, and R. May. 2014. Do water-saving technologies improve environmental flows? Journal of Hydrology 518(A):140-149. https://doi.org/10.1016/j.jhydrol.2013.11.063

Belsky, J. M. 2011. A review of "Manning, Richard. Rewilding the West: restoration in a prairie landscape." Society \& Natural Resources 24(11):1228-1233. https://doi.org/10.1080/08941920.2010.518937

Bennett, N. J., A. Di Franco, A. Calò, E. Nethery, F. Niccolini, M. Milazzo, and P. Guidetti. 2019. Local support for conservation is associated with perceptions of good governance, social impacts, and ecological effectiveness. Conservation Letters 12(4):e12640. https://doi.org/10.1111/conl.12640

Berkes, F., and H. Ross. 2013. Community resilience: toward an integrated approach. Society \& Natural Resources 26(1):5-20. https://doi.org/10.1080/08941920.2012.736605

Bixler, R. P., S. Johnson, K. Emerson, T. Nabatchi, M. Reuling, C. Curtin, M. Romolini, and J. M. Grove. 2016. Networks and landscapes: a framework for setting goals and evaluating performance at the large landscape scale. Frontiers in Ecology and the Environment 14(3):145-153. https://esajournals.onlinelibrary. wiley.com/doi/abs/10.1002/fee. 1250

Bond, W. J., and G. F. Midgley. 2000. A proposed $\mathrm{CO}_{2}$-controlled mechanism of woody plant invasion in grasslands and savannas. Global Change Biology 6(8):865-869. https://doi.org/10.1046/ j.1365-2486.2000.00365.x

Breshears, D. D., N. S. Cobb, P. M. Rich, K. P. Price, C. D. Allen, R. G. Balice, W. H. Romme, J. H. Kastens, M. L. Floyd, J. Belnap, J. J. Anderson, O. B. Myers, and C. W. Meyer. 2005. Regional vegetation die-off in response to global-change-type drought. Proceedings of the National Academy of Sciences of the United States of America 102(42):15144-15148. https://doi.org/10.1073/ pnas.0505734102

Briggs, J. M., G. A. Hoch, and L. C. Johnson. 2002. Assessing the rate, mechanisms, and consequences of the conversion of tallgrass prairie to Juniperus virginiana forest. Ecosystems 5(6):578-586. https://doi.org/10.1007/s10021-002-0187-4

Brockington, D., R. Duffy, and J. Igoe. 2012. Nature unbound: conservation, capitalism and the future of protected areas. Routledge, London, UK. https://doi.org/10.4324/9781849772075

Bromley, G. T., T. Gerken, A. F. Prein, and P. C. Stoy. 2020. Recent trends in the near-surface climatology of the northern North American Great Plains. Journal of Climate 33(2):461-475. https:// doi.org/10.1175/JCLI-D-19-0106.1

Brookshire, E. N. J., P. C. Stoy, B. Currey, and B. Finney. 2020. The greening of the Northern Great Plains and its biogeochemical precursors. Global Change Biology 26(10):5404-5413. https://doi. org/10.1111/gcb.15115 
Brown, P. M., and C. H. Sieg. 1999. Historical variability in fire at the ponderosa pine - Northern Great Plains prairie ecotone, southeastern Black Hills, South Dakota. Écoscience 6(4):539-547. https://doi.org/10.1080/11956860.1999.11682563

Brugger, J., K. Hawkes, A. Bowen, and M. McClaran. 2018. Framework for a collaborative process to increase preparation for drought on U.S. public rangelands. Ecology and Society 23(4):18. https://doi.org/10.5751/ES-10503-230418

Bullinger, J. 2017. Montana refuge divides tribes and ranchers. High Country News, April 28, 2017. [online] URL: https://www. hcn.org/issues/49.9/montana-prairie-refuge-divides-natives-and-ranchers

Buscher, B., and R. Fletcher. 2020. The conservation revolution: radical ideas for saving nature beyond the Anthropocene. Verso, London, UK.

Carter, S. K., N. B. Carr, J. R. Hickey, K. N. Rogers, and D. J. A. Wood. 2017. Understanding a landscape approach to resource management in the Bureau of Land Management. Pages 7-18 in Multiscale guidance and tools for implementing a landscape approach to resource management in the Bureau of Land Management. Open-File Report 2016-1207, U.S. Geological Survey, Reston, Virginia, USA. https://doi.org/10.3133/ ofr20161207

Cavender-Bares, J., S. Polasky, E. King, and P. Balvanera. 2015. A sustainability framework for assessing trade-offs in ecosystem services. Ecology and Society 20(1):17. http://dx.doi.org/10.5751/ ES-06917-200117

Chaffin, B. C., A. S. Garmestani, L. H. Gunderson, M. H. Benson, D. G. Angeler, C. A. Arnold, B. Cosens, R. K. Craig, J. B. Ruhl, and C. R. Allen. 2016. Transformative environmental governance. Annual Review of Environment and Resources 41(1):399-423. https://doi.org/10.1146/annurev-environ-110615-085817

Chaffin, B. C., H. Gosnell, and B. A. Cosens. 2014. A decade of adaptive governance scholarship: synthesis and future directions. Ecology and Society 19(3):56. http://dx.doi.org/10.5751/ ES-06824-190356

Charles M. Russell National Wildlife Refuge Community Working Group (CMRCWG). 2020. About us. [online] URL: http://www.cmrcwg.org/about-us/

Clark, J. S., E. C. Grimm, J. J. Donovan, S. C. Fritz, D. R. Engstrom, and J. E. Almendinger. 2002. Drought cycles and landscape responses to past aridity on prairies of the Northern Great Plains, USA. Ecology 83(3):595-601. https://esajournals. onlinelibrary.wiley.com/doi/abs/10.1890/0012-9658(2002)083[0595: DCALRT]2.0.CO;2

Collins, S. L., S. R. Carpenter, S. M. Swinton, D. E. Orenstein, D. L. Childers, T. L. Gragson, N. B. Grimm, M. Grove, S. L. Harlan, J. P. Kaye, A. K. Knapp, G. P. Kofinas, J. J. Magnuson, W. H. McDowell, J. M. Melack, L. A. Ogden, G. P. Robertson, M. D. Smith, and A. A. C. Whitmer. 2011. An integrated conceptual framework for long-term social-ecological research. Frontiers in Ecology and the Environment 9(6):351-357. https://doi. org/10.1890/100068

Conference of Parties on Biodiversity. 2016. Cancun declaration on mainstreaming the conservation and sustainable use of biodiversity for well-being.
Correll, M. D., E. H. Strasser, A. W. Green, and A. O. Panjabi. 2019. Quantifying specialist avifaunal decline in grassland birds of the Northern Great Plains. Ecosphere 10(1):e02523. https://doi. org/10.1002/ecs 2.2523

Costanza, R., R. d'Arge, R. de Groot, S. Farber, M. Grasso, B. Hannon, K. Limburg, S. Naeem, R. V. O’Neill, J. Paruelo, et al. 1998. The value of ecosystem services: putting the issues in perspective. Ecological Economics 25(1):67-72. https://doi. org/10.1016/S0921-8009(98)00019-6

Cumming, G. S., and C. R. Allen. 2017. Protected areas as socialecological systems: perspectives from resilience and socialecological systems theory. Ecological Applications 27 (6):1709-1717. https://doi.org/10.1002/eap.1584

Cumming, G. S., C. R. Allen, N. C. Ban, D. Biggs, H. C. Biggs, D. H. M. Cumming, A. De Vos, G. Epstein, M. Etienne, K. Maciejewski, R. Mathevet, C. Moore, M. Nenadovic, and M. Schoon. 2015. Understanding protected area resilience: a multiscale, social-ecological approach. Ecological Applications 25 (2):299-319. https://doi.org/10.1890/13-2113.1

Cumming, G. S., D. H. M. Cumming, and C. L. Redman. 2006. Scale mismatches in social-ecological systems: causes, consequences, and solutions. Ecology and Society 11(1):14. https://doi.org/10.5751/ES-01569-110114

Davenport, J. 2018. Making the buffalo commons new again: rangeland restoration and bison reintroduction in the Montana highline. Great Plains Quarterly 38(2):199-225. http://doi. org/10.1353/gpq.2018.0024

DeFries, R., and H. Nagendra. 2017. Ecosystem management as a wicked problem. Science 356(6335):265-270. https://doi. org/10.1126/science.aal1950

Dettenmaier, S. J., T. A. Messmer, T. J. Hovick, and D. K. Dahlgren. 2017. Effects of livestock grazing on rangeland biodiversity: a meta-analysis of grouse populations. Ecology and Evolution 7(19):7620-7627.

Dixon, A. P., D. Faber-Langendoen, C. Josse, J. Morrison, and C. J. Loucks. 2014. Distribution mapping of world grassland types. Journal of Biogeography 41(11):2003-2019. https://doi. org/10.1111/jbi.12381

Doherty, K. E., D. E. Naugle, and B. L. Walker. 2010. Greater Sage-grouse nesting habitat: the importance of managing at multiple scales. Journal of Wildlife Management 74(7):1544-1553. https://doi.org/10.1111/j.1937-2817.2010.tb01282.x

Dolan, K. A., P. C. Stoy, and B. Poulter. 2020. Land management and climate change determine second-generation bioenergy potential of the US Northern Great Plains. GCB Bioenergy 12 (7):491-509. https://doi.org/10.1111/gcbb.12686

Drescher, M., and J. C. Brenner. 2018. The practice and promise of private land conservation. Ecology and Society 23(2):3. https:// doi.org/10.5751/ES-10020-230203

Duchardt, C. J., L. M. Porensky, D. J. Augustine, and J. L. Beck. 2018. Disturbance shapes avian communities on a grasslandsagebrush ecotone. Ecosphere 9(10):e02483. https://doi. org/10.1002/ecs 2.2483 
Epstein, H. E., W. K. Lauenroth, I. C. Burke, and D. P. Coffin. 1996. Ecological responses of dominant grasses along two climatic gradients in the Great Plains of the United States. Journal of Vegetation Science 7(6):777-788. https://doi.org/10.2307/3236456

Epstein, K., L. S. Smutko, and J. M. Western. 2018. From “vision" to reality: emerging public opinion of collaborative management in the Greater Yellowstone Ecosystem. Society \& Natural Resources 31(11):1213-1229. https://doi.org/10.1080/08941920.2$\underline{018.1456591}$

Flores, D. 2016. American Serengeti: the last big animals of the Great Plains. University Press of Kansas, Lawrence, Kansas, USA.

Folke, C. 2009. Traditional knowledge in social-ecological systems. Ecology and Society 9(3):7. https://doi.org/10.5751/ ES-01237-090307

Folke, C., T. Hahn, P. Olsson, and J. Norberg. 2005. Adaptive governance of social-ecological systems. Annual Review of Environment and Resources 30(1):441-473. https://doi.org/10.1146/ annurev.energy.30.050504.144511

Forrest, S., H. Strand, C. Freese, E. Dinerstein, and J. Proctor. 2004. Ocean of grass: a conservation assessment for the Northern Great Plains. Northern Plains Conservation Network and Northern Great Plains Ecoregion, WWF-US, Bozeman, Montana, USA.

Freeman, O. E., L. A. Duguma, and P. A. Minang. 2015. Operationalizing the integrated landscape approach in practice. Ecology and Society 20(1):24. http://dx.doi.org/10.5751/ ES-07175-200124

Fuhlendorf, S. D., and D. M. Engle. 2004. Application of the firegrazing interaction to restore a shifting mosaic on tallgrass prairie. Journal of Applied Ecology 41(4):604-614. https://doi. org/10.1111/j.0021-8901.2004.00937.x

Fuhlendorf, S. D., D. M. Engle, J. Kerby, and R. Hamilton. 2009. Pyric herbivory: rewilding landscapes through the recoupling of fire and grazing. Conservation Biology 23(3):588-598. https://doi. org/10.1111/j.1523-1739.2008.01139.x

Fuhlendorf, S. D., R. W. S. Fynn, D. A. McGranahan, and D. Twidwell. 2017. Heterogeneity as the basis for rangeland management. Pages 169-196 in D. D. Briske, editor. Rangeland systems: processes, management, and challenges. Springer International Publishing, Cham, Switzerland. https://doi. org/10.1007/978-3-319-46709-2

Gerken, T., G. T. Bromley, and P. C. Stoy. 2018. Surface moistening trends in the northern North American Great Plains increase the likelihood of convective initiation. Journal of Hydrometeorology 19(1):227-244. https://doi.org/10.1175/JHMD-17-0117.1

Golding, J. D., and V. J. Dreitz. 2017. Songbird response to restrotation and season-long cattle grazing in a grassland sagebrush ecosystem. Journal of Environmental Management 204(Pt 1):605-612. https://doi.org/10.1016/j.jenvman.2017.09.044

Grant, J. A., and M. S. Quinn. 2007. Factors influencing transboundary wildlife management in the North American
"Crown of the Continent." Journal of Environmental Planning and Management 50(6):765-782.

Gray, G. J., M. J. Enzer, and J. Kusel. 2001. Understanding community-based forest ecosystem management: an editorial synthesis. Journal of Sustainable Forestry 12(3-4):1-23. https://doi. org/10.1300/J091v12n0301

Grimm, E. C., J. J. Donovan, and K. J. Brown. 2011. A highresolution record of climate variability and landscape response from Kettle Lake, northern Great Plains, North America. Quaternary Science Reviews 30(19-20):2626-2650. https://doi. org/10.1016/j.quascirev.2011.05.015

Gunderson, L., and S. S. Light. 2006. Adaptive management and adaptive governance in the Everglades ecosystem. Policy Sciences 39(4):323-334. https://doi.org/10.1007/s11077-006-9027-2

Haggerty, J. H., E. L. Rink, R. McAnally, and E. Bird. 2018. Restoration and the affective ecologies of healing: buffalo and the Fort Peck Tribes. Conservation \& Society 16(1):21-29. http:// dx.doi.org/10.4103/cs.cs_16_90

Hannah, L., G. Midgley, S. Andelman, M. Araújo, G. Hughes, E. Martinez-Meyer, R. Pearson, and P. Williams. 2007. Protected area needs in a changing climate. Frontiers in Ecology and the Environment 5(3):131-138. https://esajournals. onlinelibrary.wiley. com/doi $/ 10.1890 / 1540-9295 \% 282007 \% 295 \% 5$ B $131 \% 3$ APANIAC $\%$ $\underline{5 \mathrm{D} 2.0 . \mathrm{CO} \% 3 \mathrm{~B} 2}$

Haroldson, K. J., R. O. Kimmel, M. R. Riggs, and A. H. Berner. 2006. Association of Ring-necked Pheasant, Gray Partridge, and meadowlark abundance to conservation reserve program grasslands. Journal of Wildlife Management 70(5):1276-1284. https://wildlife.onlinelibrary.wiley.com/doi/10.2193/0022-541X\% 282006\%2970\%5B1276\%3AAORPGP $\% 5$ D 2.0.CO $\% 3$ B2

Hempson, G. P., S. Archibald, and W. J. Bond. 2017. The consequences of replacing wildlife with livestock in Africa. Scientific Reports 7(1):17196. https://doi.org/10.1038/s41598-017-17348-4

Hendrickson, J. R., K. K. Sedivec, D. Toledo, and J. Printz. 2019. Challenges facing grasslands in the Northern Great Plains and North Central Region. Rangelands 41(1):23-29. https://doi. org/10.1016/j.rala.2018.11.002

Henwood, B. 2008. Towards a conservation strategy for the world's temperate grasslands: a sense of urgency. IUCN - Temperate Grasslands Conservation Initiative, North Vancouver, British Columbia, Canada.

Henwood, W. D. 2010. Toward a strategy for the conservation and protection of the world's temperate grasslands. Great Plains Research 20:121-134.

Holmes, G. 2014. What is a land grab? Exploring green grabs, conservation, and private protected areas in southern Chile. Journal of Peasant Studies 41(4):547-567. https://doi. org/10.1080/03066150.2014.919266

Hruska, T., L. Huntsinger, M. Brunson, W. Li, N. Marshall, J. L. Oviedo, and H. Whitcomb. 2017. Rangelands as social-ecological systems. Pages 263-302 in D. D. Briske, editor. Rangeland systems: processes, management, and challenges. Springer International Publishing, Cham, Switzerland. https://doi.org/10.1007/978-3-319-46709-2 
Huitema, D., E. Mostert, W. Egas, S. Moellenkamp, C. PahlWostl, and R. Yalcin. 2009. Adaptive water governance: assessing the institutional prescriptions of adaptive (co-) management from a governance perspective and defining a research agenda. Ecology and Society 14(1):26. https://doi.org/10.5751/ES-02827-140126

Ingalls, M. L., and R. C. Stedman. 2016. The power problematic: exploring the uncertain terrains of political ecology and the resilience framework. Ecology and Society 21(1)6. https://doi. org/10.5751/ES-08124-210106

Ives, A. R., and S. R. Carpenter. 2007. Stability and diversity of ecosystems. Science 317(5834):58-62. https://doi.org/10.1126/ $\underline{\text { science. } 1133258}$

Jenkins, C. N., K. S. Van Houtan, S. L. Pimm, and J. O. Sexton. 2015. US protected lands mismatch biodiversity priorities. Proceedings of the National Academy of Sciences of the United States of America 112(16):5081-5086. https://doi.org/10.1073/ pnas. 1418034112

Jordan, W. R. 2003. The sunflower forest: ecological restoration and the new communion with nature. University of California Press, Berkeley, California, USA. https://doi.org/10.1525/9780520928480

Kendal, D., and R. M. Ford. 2018. The role of social license in conservation. Conservation Biology 32(2):493-495. https://doi. org/10.1111/cobi.12994

Knapp, C. N., N. Fresco, and L. Krutikov. 2017. Managing Alaska's National Parks in an era of uncertainty: an evaluation of scenario planning workshops. Regional Environmental Change 17(5):1541-1552. https://doi.org/10.1007/s10113-017-1126-4

Kraenzel, C. F. 1966. The Great Plains in transition. University of Oklahoma Press, Norman, Oklahoma, USA.

Laird, K. R., S. C. Fritz, K. A. Maasch, and B. F. Cumming. 1996. Greater drought intensity and frequency before AD 1200 in the Northern Great Plains, USA. Nature 384(6609):552-554. https:// doi.org/10.1038/384552a0

Lal, R. 2014. Societal value of soil carbon. Journal of Soil and Water Conservation 69(6):186A-192A. https://doi.org/10.2489/ jswc.69.6.186A

Lal, R., K. Lorenz, R. F. Hüttl, B. U. Schneider, and J. von Braun. 2013. Ecosystem services and carbon sequestration in the biosphere. Springer, Dordrecht, Netherlands. https://doi.org/10.1007/978-94-007-6455-2

Lark, T. J., J. M. Salmon, and H. K. Gibbs. 2015. Cropland expansion outpaces agricultural and biofuel policies in the United States. Environmental Research Letters 10(4):044003. http://dx. doi.org/10.1088/1748-9326/10/4/044003

Lawrence, P. G., B. D. Maxwell, L. J. Rew, C. Ellis, and A. Bekkerman. 2018. Vulnerability of dryland agricultural regimes to economic and climatic change. Ecology and Society 23(1):34. https://doi.org/10.5751/ES-09983-230134

Lipsey, M. K., and D. E. Naugle. 2017. Precipitation and soil productivity explain effects of grazing on grassland songbirds. Rangeland Ecology \& Management 70(3):331-340. http://dx.doi. org/10.1016/j.rama.2016.10.010
Madany, M. H., and N. E. West. 1983. Livestock grazing-fire regime interactions within montane forests of Zion National Park, Utah. Ecology 64(4):661-667. https://doi.org/10.2307/1937186

Marlon, J. R., P. J. Bartlein, A.-L. Daniau, S. P. Harrison, S. Y. Maezumi, M. J. Power, W. Tinner, and B. Vanniére. 2013. Global biomass burning: a synthesis and review of Holocene paleofire records and their controls. Quaternary Science Reviews 65:5-25. https://doi.org/10.1016/j.quascirev.2012.11.029

Mason, R. J. 2011. Ecoregional planning: retreat or reinvention? Journal of Planning Literature 26(4):405-419. https://doi. org/10.1177\%2F0885412211411091

McMahon, G., S. M. Gregonis, S. W. Waltman, J. M. Omernik, T. D. Thorson, J. A. Freeouf, A. H. Rorick, and J. E. Keys. 2001. Developing a spatial framework of common ecological regions for the conterminous United States. Environmental Management 28(3):293-316. https://doi.org/10.1007/s0026702429

Milligan, M. C., L. I. Berkeley, and L. B. McNew. 2020. Effects of rangeland management on the nesting ecology of Sharp-tailed Grouse. Rangeland Ecology \& Management 73(1):128-137. https://doi.org/10.1016/j.rama.2019.08.009

Montana Sage Grouse Habitat Conservation Program. 2020. About. Helena, Montana, USA. [online] URL: https:// sagegrouse.mt.gov/About

National Geographic Society. 2020. Last wild places. Washington, D.C., USA. [online] URL: http://www.nationalgeographic.org/ projects/last-wild-places/

Nie, M., and P. Metcalf. 2016. National forest management: the contested use of collaboration and litigation. Environmental Law Reporter News \& Analysis 46:10208.

Nordhaus, H. 2020. Two visions collide amid push to restore Montana plains. National Geographic. [online] URL: https:// www.nationalgeographic.com/magazine/2020/02/two-visions-collideamid-push-to-restore-montana-plain-feature/

Norman C. Wheeler \& Associates. 2019. For land's sake: Montana real estate roundup. Bozeman, Montana, USA. [online] URL: http://www.ncwheeler.com/docs/2019WesternMontananewletter. pdf

Northern Great Plains Steppe Ecoregional Conservation Team. 1999. Ecoregional planning in the Northern Great Plains steppe. The Nature Conservancy. [online] URL: https://www. conservationgateway.org/ConservationPlanning/SettingPriorities/ EcoregionalReports/Documents/ngps final feb99.pdf

Noss, R. F., E. T. LaRoe III, and J. M. Scott. 1995. Endangered ecosystems of the United States: a preliminary assessment of loss and degradation. U.S. Department of the Interior, National Biological Service, U.S. Fish and Wildlife Service, Washington, D.C., USA.

O'Connell, D., B. Walker, N. Abel, and N. Grigg. 2015. The resilience, adaptation and transformation assessment framework: from theory to application. CSIRO, Canberra, Australia.

Olimb, S. K., and B. Robinson. 2019. Grass to grain: probabilistic modeling of agricultural conversion in the North American Great Plains. Ecological Indicators 102:237-245. https://doi.org/10.1016/ j.ecolind.2019.02.042 
Olson, D. M., and E. Dinerstein. 2002. The global 200: priority ecoregions for global conservation. Annals of the Missouri Botanical Garden 89(2):199-224. https://doi.org/10.2307/3298564

Omernik, J. M. 1987. Ecoregions of the conterminous United States. Annals of the Association of American Geographers 77 (1):118-125. https://doi.org/10.1111/j.1467-8306.1987.tb00149.x

Orr, D. W. 1996. Slow knowledge. Conservation Biology 10 (3):699-702. https://doi.org/10.1046/j.1523-1739.1996.10030699. $\underline{\mathrm{x}}$

Oteros-Rozas, E., B. Martín-López, T. Daw, E. Bohensky, J. Butler, R. Hill, J. Martin-Ortega, A. Quinlan, F. Ravera, I. RuizMallén, et al. 2015. Participatory scenario planning in placebased social-ecological research: insights and experiences from 23 case studies. Ecology and Society 20(4):32. https://doi. org/10.5751/ES-07985-200432

Pecl, G. T., M. B. Araújo, J. D. Bell, J. Blanchard, T. C. Bonebrake, I.-C. Chen, T. D. Clark, R. K. Colwell, F. Danielsen, B. Evengård, et al. 2017. Biodiversity redistribution under climate change: impacts on ecosystems and human well-being. Science 355(6332): eaai9214. https://doi.org/10.1126/science.aai9214

Peterson, G. D., G. S. Cumming, and S. R. Carpenter. 2003. Scenario planning: a tool for conservation in an uncertain world. Conservation Biology 17(2):358-366. https://doi.org/10.1046/ j.1523-1739.2003.01491.x

Popper, D. E., and F. J. Popper. 1987. The Great Plains: from dust to dust. Planning 53(12):12-18.

Powell, J., B. Martin, V. J. Dreitz, and B. W. Allred. 2018. Grazing preferences and vegetation feedbacks of the fire-grazing interaction in the Northern Great Plains. Rangeland Ecology \& Management 71(1):45-52. https://doi.org/10.1016/j.rama.2017.09.003

Preston, T. M., and K. Kim. 2016. Land cover changes associated with recent energy development in the Williston Basin; Northern Great Plains, USA. Science of the Total Environment 566-567:1511-1518. https://doi.org/10.1016/j.scitotenv.2016.06.038

Pulliam, J. P., S. Somershoe, M. Sather, and L. B. McNew. 2020. Habitat targets for imperiled grassland birds in northern mixedgrass prairie. Rangeland Ecology \& Management 73(4):511-519. https://doi.org/10.1016/j.rama.2020.02.006

Ratajczak, Z., J. B. Nippert, and S. L. Collins. 2012. Woody encroachment decreases diversity across North American grasslands and savannas. Ecology 93(4):697-703. https://doi. org/10.1890/11-1199.1

Reeves, M. C., M. Krebs, I. Leinwand, D. M. Theobald, and J. E. Mitchell. 2018. Rangelands on the edge: quantifying the modification, fragmentation, and future residential development of U.S. rangelands. U.S. Forest Service General Technical Report RMRS-GTR-382.

Reeves, M. C., A. L. Moreno, K. E. Bagne, and S. W. Running. 2014. Estimating climate change effects on net primary production of rangelands in the United States. Climatic Change 126(3):429-442. https://doi.org/10.1007/s10584-014-1235-8

Roos, C. I., M. N. Zedeño, K. L. Hollenback, and M. M. H. Erlick. 2018. Indigenous impacts on North American Great
Plains fire regimes of the past millennium. Proceedings of the National Academy of Sciences of the United States of America 115(32):8143-8148. https://doi.org/10.1073/pnas.1805259115

Rosenberg, N. J. 1987. Climate of the Great Plains region of the United States. Great Plains Quarterly 7(1):22-32.

Rosenzweig, S. T., and M. E. Schipanski. 2019. Landscape-scale cropping changes in the High Plains: economic and environmental implications. Environmental Research Letters 14 (12):124088. https://doi.org/10.1088/1748-9326/ab5e8b

Sanderson, J. S., C. Beutler, J. R. Brown, I. Burke, T. Chapman, R. T. Conant, J. D. Derner, M. Easter, S. D. Fuhlendorf, G. Grissom, et al. 2020. Cattle, conservation, and carbon in the western Great Plains. Journal of Soil and Water Conservation 75 (1):5A-12A. https://doi.org/10.2489/jswc.75.1.5A

Sauer, J. R., and W. A. Link. 2011. Analysis of the North American breeding bird survey using hierarchical models. Auk 128(1):87-98. https://doi.org/10.1525/auk.2010.09220

Sayer, J., T. Sunderland, J. Ghazoul, J.-L. Pfund, D. Sheil, E. Meijaard, M. Venter, A. K. Boedhihartono, M. Day, C. Garcia, C. van Oosten, and L. E. Buck. 2013. Ten principles for a landscape approach to reconciling agriculture, conservation, and other competing land uses. Proceedings of the National Academy of Sciences of the United States of America 110(21):8349-8356. https://doi.org/10.1073/pnas.1210595110

Sayre, N. F. 2017. The politics of scale: a history of rangeland science. University of Chicago Press, Chicago, Illinois, USA. https://doi.org/10.7208/chicago/9780226083391.001.0001

Scholtz, R., S. D. Fuhlendorf, and S. R. Archer. 2018. Climatefire interactions constrain potential woody plant cover and stature in North American Great Plains grasslands. Global Ecology and Biogeography 27(8):936-945. https://doi.org/10.1111/geb.12752

Schoonover, H., A. Grêt-Regamey, M. Metzger, A. Ruiz-Frau, M. Santos-Reis, S. Scholte, A. Walz, and K. Nicholas. 2019. Creating space, aligning motivations, and building trust: a practical framework for stakeholder engagement based on experience in 12 ecosystem services case studies. Ecology and Society 24(1)11. https://doi.org/10.5751/ES-10061-240111

Şekerciŏglu, C. H., G. C. Daily, and P. R. Ehrlich. 2004. Ecosystem consequences of bird declines. Proceedings of the National Academy of Sciences of the United States of America 101 (52):18042-18047.

Sieg, C. H., C. H. Flather, and S. McCanny. 1999. Recent biodiversity patterns in the Great Plains: implications for restoration and management. Great Plains Research 9(2):277-313.

Sinclair, A. R. E., S. A. R. Mduma, J. G. C. Hopcraft, J. M. Fryxell, R. Hilborn, and S. Thirgood. 2007. Long-term ecosystem dynamics in the Serengeti: lessons for conservation. Conservation Biology 21(3):580-590. https://doi.org/10.1111/j.1523-1739.2007.00699. $\underline{\mathrm{X}}$

Sliwinski, M. S., M. E. Burbach, L. A. Powell, and W. H. Schacht. 2018. Factors influencing ranchers' intentions to manage for vegetation heterogeneity and promote cross-boundary management in the northern Great Plains. Ecology and Society 23(4):45. https:// doi.org/10.5751/ES-10660-230445 
Smith, J. T., B. W. Allred, C. S. Boyd, J. C. Carlson, K. W. Davies, C. A. Hagen, D. E. Naugle, A. C. Olsen, and J. D. Tack. 2020. Are sage-grouse fine-scale specialists or shrub-steppe generalists? Journal of Wildlife Management 84(4):759-774. https://doi. org/10.1002/jwmg.21837

Smith, J. T., J. S. Evans, B. H. Martin, S. Baruch-Mordo, J. M. Kiesecker, and D. E. Naugle. 2016. Reducing cultivation risk for at-risk species: predicting outcomes of conservation easements for sage-grouse. Biological Conservation 201:10-19. https://doi. org/10.1016/j.biocon.2016.06.006

Smith, J. T., J. D. Tack, L. I. Berkeley, M. Szczypinski, and D. E. Naugle. 2018. Effects of livestock grazing on nesting sage-grouse in central Montana. Journal of Wildlife Management 82 (7):1503-1515. https://doi.org/10.1002/jwmg.21500

Sovacool, B. K., J. Axsen, and S. Sorrell. 2018. Promoting novelty, rigor, and style in energy social science: towards codes of practice for appropriate methods and research design. Energy Research \& Social Science 45:12-42. https://doi.org/10.1016/j.erss.2018.07.007

Steiner, F. R. 1990. Soil conservation in the United States: policy and planning. Johns Hopkins University Press, Baltimore, Maryland, USA.

Stockton, C. W., and D. M. Meko. 1983. Drought recurrence in the Great Plains as reconstructed from long-term tree-ring records. Journal of Applied Meteorology and Climatology 22 (1):17-29.

Stojanovic, T., H. M. McNae, P. Tett, T. W. Potts, J. Reis, H. D. Smith, and I. Dillingham. 2016. The "social" aspect of socialecological systems: a critique of analytical frameworks and findings from a multisite study of coastal sustainability. Ecology and Society 21(3):15. https://doi.org/10.5751/ES-08633-210315

Stoy, P. C., S. Ahmed, M. Jarchow, B. Rashford, D. Swanson, S. Albeke, G. Bromley, E. N. J. Brookshire, M. D. Dixon, J. Haggerty, et al. 2018. Opportunities and trade-offs among BECCS and the food, water, energy, biodiversity, and social systems nexus at regional scales. BioScience 68(2):100-111. https://doi.org/10.1093/ biosci/bix 145

Stringer, L., A. Dougill, E. Fraser, K. Hubacek, C. Prell, and M. Reed. 2006. Unpacking "participation" in the adaptive management of social-ecological systems: a critical review. Ecology and Society 11(2):39. https://doi.org/10.5751/ES-01896-110239

Stubbs, M. 2010. Environmental quality incentives program (EQIP): status and issues. Congressional Research Service.

Stubbs, M. 2016. Irrigation in U.S. agriculture: on-farm technologies and best management practices. Congressional Research Service.

Symstad, A. J., and S. A. Leis. 2017. Woody encroachment in Northern Great Plains grasslands: perceptions, actions, and seeds. Natural Areas Journal 37(1):118-127. https://doi.org/10.3375/043.037.0114

Talley, J. L., J. Schneider, and E. Lindquist. 2016. A simplified approach to stakeholder engagement in natural resource management: the five-feature framework. Ecology and Society 21 (4):38. https://doi.org/10.5751/ES-08830-210438
Tauli-Corpuz, V., J. Alcorn, A. Molnar, C. Healy, and E. Barrow. 2020. Cornered by PAs: adopting rights-based approaches to enable cost-effective conservation and climate action. World Development 130:104923. https://doi.org/10.1016/j.worlddev.2020.104923

Taylor, K., T. Brummer, L. J. Rew, M. Lavin, and B. D. Maxwell. 2014. Bromus tectorum response to fire varies with climate conditions. Ecosystems 17(6):960-973. https://doi.org/10.1007/ s10021-014-9771-7

Toombs, T. P., J. D. Derner, D. J. Augustine, B. Krueger, and S. Gallagher. 2010. Managing for biodiversity and livestock: a scaledependent approach for promoting vegetation heterogeneity in western Great Plains grasslands. Rangelands 32(3):10-15. https:// doi.org/10.2111/RANGELANDS-D-10-00006.1

Treinish, G. 2013. Be part of one of the largest conservation efforts in American history. National Geographic Society Newsroom. December 2, 2013. [online] URL: https://blog.nationalgeographic. org/2013/12/02/be-part-of-one-of-the-largest-conservation-effortsin-american-history-2/

Turkewitz, J. 2019. Covering land and power in the American West. New York Times, June 23, 2019.

Turner, B. L. II, E. F. Lambin, and A. Reenberg. 2007. The emergence of land change science for global environmental change and sustainability. Proceedings of the National Academy of Sciences of the United States of America 104(52):20666-20671. https://doi.org/10.1073/pnas.0704119104

Twidwell, D., C. L. Wonkka, C. A. Taylor, C. B. Zou, J. J. Twidwell, and W. E. Rogers. 2014. Drought-induced woody plant mortality in an encroached semi-arid savanna depends on topoedaphic factors and land management. Applied Vegetation Science 17 (1):42-52. https://doi.org/10.1111/avsc.12044

Umbanhowar, C. E., Jr. 1996. Recent fire history of the Northern Great Plains. American Midland Naturalist 135(1):115. https:// doi.org/10.2307/2426877

United States Fish and Wildlife Service. 2012. Comprehensive conservation plan: Charles M. Russell National Wildlife Refuge, UL Bend National Wildlife Refuge. U.S. Department of the Interior, Fish and Wildlife Service, Mountain-Prairie Region.

Vold, S. T., L. I. Berkeley, and L. B. McNew. 2019. Effects of livestock grazing management on grassland birds in a northern mixed-grass prairie ecosystem. Rangeland Ecology \& Management 72(6):933-945. https://doi.org/10.1016/j.rama.2019.08.005

Walker, B. H., J. M. Anderies, P. M. Kinzig, and P. Ryan. 2006. Exploring resilience in social-ecological systems through comparative studies and theory development: introduction to the special issue. Ecology and Society 11(1):12.

Walker, T., and C. Leyshon. 2017. Resilience to what and for whom in landscape management. Pages 38-56 in E.-M. Trell, B. Restemeyer, M. M. Bakema, and B. van Hoven, editors. Governing for resilience in vulnerable places. Routledge, London, UK. https:// doi.org/10.4324/9781315103761

Wan, S., D. Hui, and Y. Luo. 2001. Fire effects on nitrogen pools and dynamics in terrestrial ecosystems: a meta-analysis. Ecological Applications 11(5):1349-1365. https://esajournals. 
onlinelibrary.wiley.com/doi/abs/10.1890/1051-0761\%282001\%29011\% 5B1349\%3AFEONPA \%5D2.0.CO $\% 3 \mathrm{~B} 2$

Ward, F. A., and M. Pulido-Velazquez. 2008. Water conservation in irrigation can increase water use. Proceedings of the National Academy of Sciences of the United States of America 105 (47):18215-18220. https://doi.org/10.1073/pnas.0805554105

Western Sustainability Exchange. 2019. Montana Grasslands Carbon Initiative. Livingston, Montana, USA. [online] URL: https://www.westernsustainabilityexchange.org/soil-carbon

Whatmore, S. J., and C. Landström. 2011. Flood apprentices: an exercise in making things public. Economy and Society 40 (4):582-610. https://doi.org/10.1080/03085147.2011.602540

Whelan, C. J., D. G. Wenny, and R. J. Marquis. 2008. Ecosystem services provided by birds. Annals of the New York Academy of Sciences 1134(1):25-60.

Whitlock, C., W. Cross, B. Maxwell, N. Silverman, and A. A. Wade. 2017. 2017 Montana climate assessment: stakeholder driven, science informed. Montana Institute on Ecosystems, Montana State University and University of Montana, Bozeman and Missoula, Montana, USA. https://doi.org/10.15788/ M2WW8W

Whyte, K. 2018. Settler colonialism, ecology, and environmental injustice. Environment and Society 9(1):125-144. https://doi. org/10.3167/ares.2018.090109

Williams, J. W., B. Shuman, and P. J. Bartlein. 2009. Rapid responses of the prairie-forest ecotone to early Holocene aridity in mid-continental North America. Journal of Global and Planetary Change 66:195-207. http://dx.doi.org/10.1016/j. gloplacha.2008.10.012

Wilmer, H., J. D. Derner, M. E. Fernández-Giménez, D. D. Briske, D. J. Augustine, and L. M. Porensky. 2018. Collaborative adaptive rangeland management fosters management-science partnerships. Rangeland Ecology \& Management 71(5):646-657. https://doi. org/10.1016/j.rama.2017.07.008

Wilson, E. O. 2016. Half-earth: our planet's fight for life. W. W. Norton \& Company, New York, USA.

Wishart, D. J. 2006. Natural areas, regions, and two centuries of environmental change on the Great Plains. Great Plains Quarterly 117:147-165.

World Wildlife Fund. 2018. The plowprint report: 2018. Bozeman, Montana, USA. [online] URL: https://c402277.ssl.cf1.rackcdn. com/publications/1171/files/original/PlowprintReport_2018_FINAL 082318LowRes.pdf?1535470091

Wyborn, C., A. Datta, J. Montana, M. Ryan, P. Leith, B. Chaffin, C. Miller, and L. van Kerkhoff. 2019. Co-producing sustainability: reordering the governance of science, policy, and practice. Annual Review of Environment and Resources 44 (1):319-346. https://doi.org/10.1146/annurev-environ-101718-033103

Zedler, P. H. 2007. Fire effects on grasslands. Pages 397-439 in E. A. Johnson and K. Miyanishi, editors. Plant disturbance ecology: the process and the response. Academic Press, San Diego, California, USA. https://doi.org/10.1016/B978-012088778-1/50015-7 